Comparative Philosophy Volume 13, No. 1 (2022): 101-118

Open Access / ISSN 2151-6014 / www.comparativephilosophy.org

https://doi.org/10.31979/2151-6014(2022).130108

\title{
THE CONCEPT OF MYTH IN KŌSAKA MASAAKI AND MIKI KIYOSHI'S CRITIQUE
}

\author{
FERNANDO WIRTZ
}

\begin{abstract}
This paper explores the concept of myth in two books written by Kosaka Masaaki, The Historical World (1937) and Philosophy of the Nation (1942). In both, myth appears as a central moment in the transition from primitive to modern societies. The role of myth is closely related to Kōsaka's notion of nature, since one goal of his reflection is to show how history is supported by the "substratum" of nature. In this sense, he also distinguishes between the natural and historical aspects of nations. After analyzing the subcategories of primordial nature, environmental nature, and historical nature, the paper shows how these layers are articulated by myth. Authority, in the contractual form of potlatch, signalizes the moment of transition to the true self-determination of nations. Miki Kiyoshi was one author who pointed out the problematic aspects of Kōsaka's theory of nation. A comparison with Miki's thought uncovers how authority is the main characteristic of Kōsaka's view of myth. The paper finishes by investigating where this authority comes from. Since it cannot come from nature alone, it should also come from the past character of myth itself, which is an expression of what Kōsaka terms "the eternal now".
\end{abstract}

Keywords: authority, eternal now, Kōsaka Masaaki, Miki Kiyoshi, myth, nature

\section{INTRODUCTION}

This article explores the philosophical and political roles of myth in the philosophy of Kōsaka Masaaki. How do nations ${ }^{1}$ define themselves as such? What roles do nature and

WIRTZ, FERNANDO: Postdoc Fellow, Center for Interdisciplinary and Intercultural Studies, University of Tübingen, Germany. Email: fernando.wirtz@uni-tuebingen.de

\footnotetext{
${ }^{1}$ Kōsaka employs the word 民族 (minzoku), which has complex connotations. Some authors (for example, Sakai 2007 and Harootunian 2019) translate it as "folk", building an intentional association with the German nationalist notion of Volk. Other possibilities are "race", "people", "ethnic group", "ethnic nation", etc. All these different possibilities are present, for example, in Goto-Jones' collection of essays Re-Politicising the Kyoto School as Philosophy (see Goto-Jones et al. 2008). I opted for "nation", which is more neutral, because Kōsaka himself seems to translate "natio" with it, in contrast to “populus" (市民) (see Kōsaka 1942, 6). By contrast, in the case of 種族, I opted for "ethnic group", since Kōsaka uses it to highlight the ethnic dimension of nations.
} 
myth play in the configuration of national identities? These are questions that caught the attention of Kōsaka, and his reflections are important in comprehending how the concept of myth - without overlooking its relation to politics or aesthetics - can be thought of as possessing a certain autonomy.

Kōsaka Masaaki was born in Nagoya in 1900. After attending Yotsuya High School, he studied philosophy, graduating from the Department of Philosophy at Kyoto Imperial University in 1923. There, he studied under Nishida Kitarō and Tanabe Hajime and shared the same intellectual atmosphere as Miki Kiyoshi and other members of the Kyōto School. After graduation, he took positions at different universities. Finally, in 1940, he became a professor at Kyoto Imperial University and, one year later, he became the Director of the Institute for Humanities.

Immediately after the war, Kōsaka was banned from public office, but in 1955 he became Dean of the Faculty of Education at Kyoto University and in 1961 President of Tokyo Gakugei University. In 1966, he served as the head of a special committee of the Central Council for Education. He died on December 9, 1969, and the publication of his Collected Works in eight volumes was completed a year later.

In addition, as a student of Nishida Kitarō and a professor at Kyoto University, Kōsaka's thinking is crucial to obtain a full understanding of the philosophy of the socalled Kyoto School. Usually, Nishida, Tanabe Hajime, and Nishitani Keiji are considered the three main authors of this school. For this reason, Kōsaka's production is an understudied object among Kyoto School scholarship (both in and outside Japan). ${ }^{2}$ Another explanation for this is his reputation as a conservative and nationalist thinker. In this regard, he is known mostly for having participated in the infamous round-table discussions that took place between 1941 and 1942, published by the magazine Chūo Köron (中央公論, Central Review) under the title The World-Historical Standpoint and Japan (世界史的立場と日本, 1943). During these talks, Kōsaka, together with the other orators Nishitani Keiji, Suzuki Shigetaka, and Koyama Iwao, made use of a rhetoric filled with nationalistic and pro-war motives in what became one of the most controversial episodes in the history of this philosophical tradition.

As important as these debates were, I would like to focus here instead on another aspect of Kōsaka's thought: his reflections on myth. He left traces of his deep appreciation of mythology in the pages of disparate texts, including The Historical World (歴史的世界, 1937), Myth (神話, 1940), and Philosophy of the Nation (民族の 哲学, 1942). In this article, I will reconstruct Kōsaka's theory of myth using The Historical World and Philosophy of the Nation, since it is in these books that myth becomes a central moment of the formation of a nation. ${ }^{3}$

What is the role of myths in the constitution of political groups? Certainly, this question can be answered from many perspectives, but there is a general theoretical agreement with the notion that myths offer a collective narrative able to inspire or to construct forms of political identity. The history of Japan offers some examples in this direction. In the period from the Meiji Restoration in 1868 to the Second World War,

${ }^{2}$ Hanazawa 2008 is the only recent monograph published on Kōsaka's philosophy.

${ }^{3}$ Myth is a collection of essays focused on concrete aspects of Greek mythology. 
it is possible to observe a consistent evolution of state Shintō (see Antoni 2002 and 2011). Usually, Shintō (神道) is described in a simplified way as the autochthonous religion of Japan, which centers on the figure of nature deities known as kami (神). The two traditional main sources of Shintō mythology are the Kojiki and the Nihonshoki (probably written in the 7th and 8th centuries), which, especially after the philological scholarship of the 18th century, acquired a certain status as unofficial Shintō "holy books." These texts are also relevant because they offer the official genealogy of the Imperial House. In particular, they place the imperial family as direct descendants of the sun goddess Amaterasu Ōmikami, thus building a continuous lineage that would be central to the nationalist ideology of the interwar and war periods. This aspect was very important in the 1930s when there was a conjunction between the mythical figure of the emperor and the concept of kokutai (国体) or national polity. ${ }^{4}$ Although the concept of kokutai itself had a long history, it became quite central in the political debates of that time. In a period when the Japanese government was interested in building a strong national identity, the heterogeneous canon of these mythologies nevertheless offered a solid repository for the project. One example illustrating this sensibility toward myths is the constitutional scholar Minobe Tatsukichi, who was accused in 1935 for his liberal theory of the "Emperor as an organ of the government" (天皇機関説), which shifted the centrality and absoluteness of the monarch. Another representative case is Tsuda Sökichi and his historical analysis of the myths of the Kojiki and the Nihonshoki (for a detailed account of this, see Isomae 2010).

These examples should not suggest a Shintōist palimpsest behind the concept of myth employed during the 1930s. Rather, what is important to remark is that the concept of myth was widely thematized and that political, philological, and philosophical interests collided and superposed each other. In fact, Kōsaka is not interested in the particularities of Japanese mythology. Indeed, he is more familiar with the new studies on Greek and primitive mythology than that of Shintō. In this context, Kōsaka's philosophy shows a different way in which myth was used to think about the nation. Because myth connects the nation with its natural soil, in the first section I provide an overview of Kōsaka's complex, three-layered conception of nature. He distinguishes between primordial, environmental, and historical nature. These three dimensions are intertwined and suggest that history is not to be conceptualized as something isolated from nature. In the second section, I give a brief analysis of the core concept of myth, which represents the manifestation of collective authority. Afterwards, I elaborate on the previous point, comparing Kōsaka's and Miki's concept of myth. These authors shared not just an intellectual milieu and an affinity with Nishida's teachings but also an interest in myth and tradition. ${ }^{5}$ Nevertheless, their positions were not completely compatible. A proof of this is the conversation they had transcribed in the pages of the journal Bungei (文芸). By discussing the points where they clash, I show how Kōsaka's conception of authority does not completely solve the de-

\footnotetext{
${ }^{4}$ Lit. "nation-body."

${ }^{5}$ One of the few authors who highlighted the contact points between Kōsaka and Miki is Hase 2002, 314-316.
} 
naturalization of nationality (as he supposedly intends to do). The final section proposes a reading of Kōsaka's theory of myth that moves beyond the reification of authority. The central thesis of my paper is that one of the fundamental elements introduced by Kōsaka is the irreducible temporality of myth. Myth appears as the way to mediate past and authority. In this sense, Kōsaka subverts pragmatist and functionalist interpretations of myth.

\section{THE NATURAL SUBSTRATUM OF HISTORY}

At the center of Kōsaka's work lie the concepts of history and nation. In a nutshell, nations are for Kōsaka the subjectivation of a process that he calls the "historical world". This is also the name of his most famous book, The Historical World (歴史的世界), which was published in 1937, although its chapters had started to appear as individual essays in the journals Shisō and Tetsugaku Kenkyū as early as 1933. In the book, it is possible to already find all the central elements of Kōsaka's philosophy.

Important for the aim of the present paper is the way in which Kōsaka explains the relation between nature and history. Particularly important is the way in which nations, which are understood as historical subjects, arise "in the middle" of the natural world. Traditionally, nature and history are thought of as opposing poles. While nature is the realm of instincts, necessity, and regularity, history is the kingdom of agency, freedom, and contingency. Kōsaka, as a Kyōto School philosopher, is committed to the idea that the last ground of reality is nothingness. In this sense, he is aware that history cannot be determined by any transcendental or purely ideal forces. The course of history cannot be the result of a transcendental plan or a predicted destiny. It can be neither the deterministic development of any innate or genetic given factors. However, this assumption generates clear friction with the concept of nature. Even if human beings, the participants of history, are supposed to be free, they are certainly tied to their natural bodies and their environment. Moreover, everything that is called a historical event takes place within the world of nature.

To this end, Kōsaka cannot resort to the idea of a supernatural temporality, for that would entail one of the abstractionist sins of Western philosophy. In any case, what is called nature appears to be previous to history, in the sense of something pre-historic. To think about this precedency without reducing it to an ontological and chronological priority, Kōsaka recognizes the principle of historical time in the “eternal now" (永遠

の今), a concept that he inherits from Nishida. Contrary to what its name would indicate, the so-called eternal now does not transcend time; it is not eternal as separated from time but refers rather to the place of immanence in which the mediation between past, present, and future arises. For this reason, the eternal now has to be dynamic. To cast this processual dimension, Kōsaka makes use of Schellingean terminology, stating that there should be something within the eternal now that is not the eternal now (such as Schelling's Natur in Gott) (see Kōsaka 2002, 142-143). Kōsaka calls this dark ground "primordial nature" (源治自然). If there can be such a thing as a ground of history, this cannot be completely a-historical. This is the premise of Kōsaka's notion 
of nature. "This is because the substratum [基体], by giving birth to history, conversely gives birth to itself" (Kōsaka 2002, 135). This "giving birth" is in itself historic because it creates something new. As in the case of Schelling, this primordial nature is not a closed essence but something that moves toward something outside itself. "To say that the negative side of the eternal now is primordial nature is to say, on the contrary, that primordial nature has a longing for eternity, an impulse toward ideals, and the chaos has a tendency toward the world" (Kōsaka 2002, 145).

However, to truly function as the grounding of historical actions, nature cannot remain an invisible force; it has to become concrete. This emergent dimension of nature is what Kōsaka terms “environmental nature” (環境的自然). Unlike Schelling, Kōsaka does not have a cosmological explication for this transition, and it remains unclear how primordial nature becomes objective. The instantiation of environmental nature has a quasi-historical character. "As freedom is born, it makes its own ground into a boundary, into an environment" (Kōsaka 2002, 152). It is also through action that primordial nature becomes an object for human beings, since no freedom is possible without something that resists it.

The notion of environmental nature is subdivided by Kōsaka. Its two layers are the "external environment" and the "internal environment" and, as with any other dimension of the historical world, they have to be considered co-original. These layers are also the two immediate conditions for the formation of nations (they are necessary but not sufficient). Under "external environment", Kōsaka understands what Watsuji Tetsurō calls füdo (風土), that is, the "climate" as an existential factor of human development (and not just as something material). Human beings are not determined by their $f \bar{u} d o$ - they also transform nature with their activities and even allow some other organisms to subsist. ${ }^{6}$

Certainly, then, "human beings create a humanized natural world" (Kōsaka 2002, 162). However, as stated in Friedrich Ratzel's Anthropogeographie (see Ratzel 1909, 26-41), the work that Kōsaka at this point refers to, climate and soil are insufficient to explain the configurations of an ethnic group. Together with this spatial element (i.e., the soil) 土), Kōsaka highlights the importance of a temporal one: blood relations (血 族). This is certainly one of Kōsaka's most problematic concepts. He is well aware of the racist connotation of the term, and in his book Philosophy of the Nation, he distances himself from authors such as Joseph Arthur de Gobineau by drawing on Frederick Hertz's critique of Rassendeterminismus (race-determinism) (see Hertz 1915, 4). Notwithstanding, Kōsaka does not give up the idea that a nation, to be considered as such, needs environmental and generational support. However, unlike in theories of race that pretend to follow the method of the natural sciences, Kōsaka states that the ethnic element of a nation has to be simultaneously historical.

\footnotetext{
6 "The repetitive gaining of productivity through fertilizers and the transformation of grasslands and forests into cultivated lands will also teach us this. If the life force of the soil is recognized only in the organisms that thrive there, and deserts are dead soil because they do not allow organisms to live, then many of the lands we encounter owe their organisms to human mediation" (Kōsaka 2002, 161). See also Harootunian 2019, 266.
} 
As stated above, the external and internal environment are disclosed as something self-contradictory. The biological body depends on geography, and geography is transformed by human agents. It is the mediation between both, their contradiction, that creates the logic of the world's dynamic. However, it is also precisely because of this contradiction that Kōsaka discovers what he calls "historical nature” (歴史的自然). "Nature is the birthplace of the spirit, the preliminary stage of the spirit, and the prehistory of the spirit. Nature gives birth to history and is the precondition and prehistory of the historical world. Nature [in this sense] becomes a part of history. By being the source of history, nature negates itself and becomes historical" (Kōsaka 2002, 179-180). Thus, despite being "outside" history, nature is condemned to be historical.

\section{MYTH AS POTLATCH}

The next aspect to explore is the role of myth in Kōsaka's view of history. Throughout his book, Kōsaka refers to primordial nature using the German word Mutter Erde (Mother Earth), and his references here are clearly mythological: he quotes, for instance, Johann Jakob Bachofen, Albrecht Dietrich, and Erwin Rohde (see Kōsaka 2002, 135, 160). Although he does not further explain how the myths of Mother Earth relate to the historical world, it is patent that myths offer intuitive access to the philosophical constitution of reality. "The fact that customs are analogous to myths and legends is not only because they show a relationship with the divine. Just as myths show the connection between a nation and its nature, so do customs show how a people have incorporated nature into their lives" (Kōsaka 2002, 72). One of Kōsaka's main influences here is unequivocally the sociologist Ferdinand Tönnies, who was extremely interested in social phenomena as custom, public opinion, fashion, and so on:

The true substance of the common will in a fixed people, on which therefore numerous individual habits are based, is its custom [Sitte]. We have noticed how to the community of blood the community of the land, the homeland, with new effects on the minds of the people, therefore, partly as a substitute, partly as a supplement, is added. The land has its own will, which binds the savagery of unruly families. As the woman giving birth represents the temporal connection of human bodies sensually, adding a new ring to the chain of life, so the land means the togetherness of a multitude living at the same time, which must be directed according to the rules embodied in it, as it were. (Tönnies 1922, 214)

For Kōsaka, the spiritual and political authority within a society always requires some kind of reference to the mythical (see Tönnies 1909, 33). For Tönnies, the myth is understood as a form of custom (Sitte), which he conceives as the expression of a "people's will" (Volkswille), contrary to habit (Gewohnheit), which is individual (Tönnies 1909, 16-17). In fact, Tönnies seems to suggest that the origin of a custom is itself mythical, since many customs find their source of legitimacy in a heroic or divine "lawmaker" from the distant past (Tönnies 1909, 18). For this same reason, the "veneration of the dead" is also one of the more fundamental forms of custom, which Tönnies calls "the custom of customs" (die Sitte der Sitten) (Tönnies 1909, 21). 
Kōsaka's concept of myth also has some resemblances to Hans Freyer's book Der Statt (first edition 1925), a work known and quoted by Kōsaka (2002, 215). Myth, cult, and language are the three systems that form the spiritual and objective basis of a state. Freyer, the successor of Tönnies at the German Sociological Association and infamous for his sympathies for National Socialism, conceives the myth as a cultural environment of signs, a world of concrete significations, which places human beings in their world:

But just as language is elevated to a higher significance by the political turn of the spirit, so myth is no longer merely the horizon of the people's lives, but infinitely more: a symbol of their unity, an objective good taken from the arbitrariness and taste of the living generation, the objective norm for belonging to the people and for the people's loyalty to themselves. Symbols and landmarks are not understood elsewhere; wisdoms and riddles are not valid elsewhere; the image of the homeland and the song of its history; the song of heroism, forbearance, and fate-embraced life-all this binds the world of the empire together at once wholly from without and wholly from within: as the spiritualization of its outermost perimeter and as the giving of form to the most secret vibrations of its spirit. And which wise men and poets have given name and memorable melody to this incomprehensibility, they have not drawn from their own, but from the faith of the people, and they have not created works, but have built the state. (Freyer 1926, 127)

Through these romantic or even vitalist words, it becomes more clear that myth works as a system of identification. Myth is also a product of the people and not from poets. Again, it is something located on the diffuse border between nature and society. In the quote, Freyer refers to the moment in which myth is separated from its religious origins and reterritorialized in the field of political institutions. This is a point that Kōsaka will also deal with, since the connection between the nation and nature cannot be one of pure amalgamation. Besides this natural signification, Kōsaka locates the importance of mythology in the transformation of authority, a moment that moves beyond nature. The broader point here is that, for Kōsaka, myth assumes the form of a field of significance that imbues society with a certain legitimacy. Beyond the idea of a national landscape, Kōsaka does not give examples of concrete myths. He does not even mention Japanese folklore. For him, myth is a general sociological category; it is a layer of signification. In this sense, Kōsaka is asserting that all societies have a need for myth.

Myths are used as categories of analysis, both for so-called primitive societies and for our current societies. One of the main contributions of sociology and anthropology in the early 20th century was, in fact, to demonstrate how myths exist not only in the remote past but are observable in all human societies. This is an idea also shared by Kōsaka's teacher, Nishida, who wrote in 1935: "What unifies a Gemeinschaft is the mythical [ミュトス的]. It is said that totems are not necessarily relations of blood relatives. In that fact, cultural will is already at work. Without tradition, there is no culture. Thus, tradition begins with myth" (Nishida 2012, 127/NKZ 8, 194). ${ }^{7}$ Nevertheless, whereas for Nishida, at least in this text, the mythical seems to be the

\footnotetext{
${ }^{7}$ For a deeper analysis of tradition and myth in Nishida's work, see Zavala 2004, 223-263.
} 
vehicle of culture, for Kōsaka, myths are the vehicles of an authority. For Kōsaka, authority implies a political force that is recognized as valid by a group. This validity is what gives self-sufficiency and legitimacy to the group itself as such. In this sense, one of the main functions of myth for Kōsaka is the mediation with authority. Since in both The Historical World and Philosophy of the Nation mythology is related to authority, dwelling on this point is necessary.

The transition from ius naturale to ius positum seems, for Kōsaka, to be mediated by myth. In Philosophy of the Nation, Kōsaka follows Georges Davy's and Alexandre Moret's explanation to describe the transition from totemism to modern societies. According to Davy and Moret, the political development of a society is reflected in the transformation of its mythology. They recognize a three-stage passage in which the sacred moves from the representation of mana - as an impersonal vital force - to the collective individualization of the totem - in which the group obtains its identity as a tribe by being bearers of one common totem - and finally the potlatch, which creates, for the first time, a unified co-fraternity around an individualized power (see Kōsaka 1942, 54). That is, for Kōsaka, the true individualization of authority appears with the potlach, since the totem is just a partial one (the totem represents a "collective individual"). That is why modern politics begin with the potlach, because here we have the idea of the individual as political actor. Kōsaka takes this historical typology from Davy and Moret without questioning it. The difference is that, while for Davy and Moret mythology is a reflection of politics, for Kōsaka, politics needs myths to operate.

It is the latter, the potlatch, which represents a moment of discontinuity between a pre-contractual organization and a contractual one. To put this complex phenomenon simply, the potlatch can be described as a rite or feast in which one or more members of the community give away part or all of their wealth, sharing or destroying food or other valuable objects. By doing this, Davy and Moret remark, the person who organizes the feast gains prestige but also a kind of authority. In the words of these scholars: "In the course of this transformation of the hereditary rules of kinship, and thanks to the very vagueness which the transition created, the hereditary method of acquiring the totem finds a rival in a new method, the contractual" (Moret and Davy 1926, 86). The contractual moment of this might be found, according to Mauss, in the following fact: "Time has to pass before a counter-prestation can be made" (Mauss 1966, 34). By giving away, the person enters into a contractual relation with the community. Personal prestige implies an interruption of the hereditary transmission of power. In this sense: "To rid himself of the rivalry of collective totemic inheritance, the chief absorbs and symbolizes this inheritance in himself. He gives himself out as the hereditary owner of the totem. And it is thereby that he becomes chief" (Moret and Davy 1926, 85).

Nevertheless, Kōsaka is not purely a functionalist (see Kōsaka 1942, 46-49). While naturalistic theory attempts to explain myths as a manifestation of the precarious scientific attitude of peoples, historical theory interprets them as precarious historical accounts. Both start from the premise that myths are the result of some kind of undeveloped capacity of the human spirit. Inversely, functionalism—and Malinowski counts as one of its main exponents - investigates the social function of myths, that is, 
into the way in which myths offer actual solutions to practical community problems. Although Kōsaka acknowledges the importance of the functionalist perspective, he also recognizes certain shortcomings in its attempt to explain some myths exclusively in terms of economic exchange. For him, the potlatch is not a pure economic or political phenomenon. On the contrary, "it has a metaphysical background that simply cannot be established economically or empirically" (Kōsaka 1942, 61).

In The Historical World, Kōsaka analyses different forms of cultural transmission. For example, he differentiates “anecdotes” (逸話) from “legends” (伝説). “Whereas anecdotes tend merely toward idolatry, legends are more concerned with the establishment of a guardian deity or demon of an ethnic group [種族] or nation [民族]" (Kōsaka 2002, 46). Here, again, there is a qualitative leap from the pre-communitarian to the communitarian itself. Broadly speaking, the protagonists of myth (and legends) are not human beings, but deities. They can refer also to the ancestors, but as entities beyond the present. A "guardian deity" represents the mythical manifestation of an entity that goes beyond the manifestation of the local group, since it gives a corporeality to something that will assume the form of the "public". Here, Kōsaka is thinking of the cult of protective deities, sometimes called genii (for example, in the case of the expression Genius populi Romani), where the deity assumes the character of a certain collective identity. This is why Kōsaka describes public opinion (輿論) as mythical. I quote this passage in full. Kōsaka writes:

I would just like to note here that public opinion is always accompanied by some authority. But that authority is often combined with a living folklore that is mythical. Why, then, does public opinion need to be mythical? The authority of public opinion is based on the fact that it is not the will of the individual, but the will of the collective. Public opinion means something that has an authority, and it is not questioned whether it is right or wrong. It is here that people do things like hiding behind public opinion and inciting public opinion. Public opinion has the character of a taboo. But then, why does public opinion include something that is folklorical within itself? Mythology, as we have already seen, is demonic and has a magical character. The living mythology of our time, insofar as it is also folklorical, contains such magical effects, and thus plays a role of authority in public opinion. Every nation and every age has such a folklore. Without it, history will not move. Perhaps every state has a folklore about the land that is specifically designated for that nation, a folklore about the sacred land. One should think of the German folklore about the Rhine, for example. This is where the meaning of the myth of incorporating nature into oneself can also be found. Why, then, does folklore have such an authority? One must not disparage folklore as mere myth [単なる神話]. Folklore has many harmful effects, but without it, history would not be able to move. Moreover, we are also too enlightened to believe in myths as mere myths. What attitude should we take toward such folklore? What meaning does it have for us? (Kōsaka 2002, 52-53)

This passage is extremely relevant to understanding the role of mythology. We find here that public opinion receives its authority from mythology. These discourses and beliefs have a "natural" constitution and, because of this, Kōsaka refers to them as the periphery of history. Traditionally, modern politics is based on the authority of reason 
and logos. Nevertheless, what Kōsaka supports is the idea that even within modern societies there are mythical elements that are justified through the eternal now. At the same time, Kōsaka does not give concrete examples of what these myths are, but he refers again to the "land." The myths of nature do not involve deliberation in the sense that no person decides where to be born. There are certain narratives related to the land that are "always there," always available in the public sphere. Because they refer to a mythical past, they are located on the periphery of history. They are not history itself but that which can become the raw material of history. But public opinion-and perhaps, we could add, common sense - has to search for its authority outside itself. It cannot subsist as something independent. A comparison between Kōsaka and Miki will shed some light on the complex relation between myth and authority.

\section{THE AUTHORITATIVE CHARACTER OF THE PAST AND MIKI'S CRITIQUE}

Where does the authority of myth come from? In the previous section, this question was left unanswered. Kōsaka's solution seems to be that the mythical character of "being already there", its givenness, has something to do with the authority of myth:

In folklore, we have seen guardian deities. So what is the basis of its authority? Regarding folklore, we are commanded to accept it wholeheartedly. What is the basis of this overbearing authority? It may be based on various reasons. But what is interesting to us, in connection with what will be discussed later, is that the mythical has the character of "already existing," as we have already said. We have also said earlier that the newer the gossip, the more valuable it is, while the older the legend, the more valuable it is. This is also related to the character of "already" [既に]. So, why is that? The fact that a myth is like a guardian deity means that it has some kind of foundation for a nation. Why, then, does the character of "already" have a foundational meaning? (Kōsaka 2002, 53)

That which impregnates its authority into myth is its character of "already." This "already there," however, is not a heritage of something static that is merely superimposed on the present. This idea can be illustrated as follows. The difference between customs and traditions is that the former do not rely on self-awareness, whereas the latter do. While customs rely on power (Gewalt), traditions rely on authority (Autorität) (Kōsaka 2002, 79). ${ }^{8}$ For this reason, according to Kōsaka, traditions are transmitted within the “continuity of discontinuity" (非連続の連続) (Kōsaka 2002, 78). "Historical knowledge can only be accessed and recognized as such when it is mediated by transmissions from the past" (Kōsaka 2002, 76). That is, traditions are actively selected, re-appropriated, and enacted in the present. Tradition could be interpreted here as a crystallized form of custom mediated by the mythical.

A very similar idea is found in the philosopher Miki, particularly in his article, Historical Consciousness and Mythical Consciousness, published in 1934, three months before Kōsaka's chapter on tradition and legends. Also, for Miki, the past is

${ }^{8}$ For this distinction, see Weber 1922, 122. 
not simply repeated in the present and reproduced objectively. The past is always “attracted” (手繰り寄せる) or “brought up” to the present (MKZ 10, 329). Miki also points out the important character of the "already there". He writes:

History is held by the consciousness of the present. Thus, mythical consciousness can live from the consciousness of the present. We discover the origin of mythical consciousness in pathetic consciousness. In this sense, the consciousness of the logos is objective consciousness, and its objectivity is defined by its character as "already." With respect to the object, no matter what it is that we want to begin with, there is always something that is already given. This is presently there, but this "presently" [現に] is not separated from its sense as “already" and therefore possesses a pastness [過去性]. Pathetic consciousness is truly consciousness of the present. This is not something objective but subjective consciousness. (MKZ 10, 330-331)

At first glance, it would seem that Miki agrees with Kōsaka. However, there is a subtle difference. For Miki, the "already" does not exhaust the content of the mythical, as the mythical is also "pathetic" (パトス的). That is, it depends on the embodied situation of the present that affects the agents. In contrast, Kōsaka emphasizes a primordial dimension that can be actualized: "Moreover, true recurrence means that the past must be brought back to life from its roots [根源加ら]” (Kōsaka 2002, 78).

It is true that Kōsaka does not completely disregard the role of affectivity. It could be said that, for Kōsaka, myth implies an affectivity toward the past. Both Kōsaka and Miki refer to the mythical as something "dämonisch", and this is certainly something receptive. ${ }^{9}$ Miki takes the expression from Goethe:

In other words, according to Goethe, the demonic is not ideal, but rather natural, accidental, yet still inevitable. [...] He further stated that the demonic always accompanies every Leidenshaft [passion]. Of course, [the demonic] cannot be separated from some negative meaning, but this is not purely destructive-negative but rather "manifests itself in a totally active positive force." (MKZ 2, 378) $)^{10}$

On the other hand, Kōsaka is familiar with Frobenius' book Paideuma, where the demonic refers to the mythical and childhood-like stage of humanity. There, we read: "The affect is a natural shock, which is necessary to awaken the demonic-genial" (Frobenius 1921, 62-63). In this sense, the mythical-demonic is the creative condition of a certain affectivity toward the past, toward the given. It is also true that both Kōsaka and Miki grasp this mythical affectivity as something that cuts into the temporality of everydayness. The difference here is that, for Kōsaka, that which disrupts the present

\footnotetext{
${ }^{9}$ For Miki, the demon is the "pathetic that became mythical" (see MKZ 10, 333).

${ }^{10}$ Another important aspect of the Dämonisch is that it moves in-between worlds. "In essence, Goethe seems to suggest that the daemonic is neither immanent nor transcendent; rather, it tends to escape this kind of distinction, and indeed the confines of conceptual thought, altogether" (Nicholls 2006, 229). This is also important for Miki and Kōsaka, since the mythical for them is also a moment of transition.
} 
is the authority, whereas for Miki, that which dislocates the temporality is the possibility of a social change. Let us start with Kōsaka. He writes:

The fact that we have a past means that we have a biography, and this is what makes us valuable in the present. The past is the foundation of the present in this sense. The spatial is horizontal, and horizontalization is the dissolution of the mystical and threatening, which was the basis of gossip [噂話], but in legend, the everyday is mystified and made authoritative. This is because the temporal can be considered to indicate the direction of deepening in relation to the spatial. This is one of the reasons why, for example, bad precedents have become binding because they have the character of "already" as precedents. It is only natural that folklore should have the character of "already." Public opinion, by including folklore, includes [also] the foundation of the past and confirms its authority. (Kōsaka 2002, 54)

A very similar characterization is found in Miki's text Introduction to Social Science (社会科学概論) (1932), where he distinguishes between doxa and myth. ${ }^{11}$ The former is the form of social knowledge that represents the "common sense" of a given society during periods of stability and harmony. It is the knowledge that circulates among the different strata, creating a shared discursive order. Myths, by contrast, are elements of dislocation. Myths are forms of social knowledge that arise during times of distress. Myths are therefore the consciousness of historical contradiction and, by recognizing the crisis, they are able to create an alternative image of the present. In this sense, Miki says that while doxa has a spatial nature, mythos has a temporal one (see MKZ 6, 308-309). Myths can offer a new beginning. ${ }^{12}$

As can be inferred from these premises, a parallel may be drawn between Kōsaka's notion of gossip and the doxa in Miki. Both function as the adherent medium that holds together the order of the status quo. Myth, however, implies a vertical force able to create a temporal dislocation by means of a radical narrative. In the case of Miki, this interpretation was inspired by Sorel. In fact, Miki's first approach to the concept of political myth is through Sorel, as can be seen in his text The Philosophy of Pragmatism and Marxism (プラグマチズムとマルキシズムの哲学) (1927). Already here, it is evident that Miki understands the potential of myth to articulate social action. Miki writes there:

The mythe gives us the revolution as a whole, and therefore it does not allow us to disassemble the revolutionary movement into the series of static fragments that seem to constitute it. The fallacy of all reformism, rational parliamentarism, etc. lies in the idea that a movement that should be indivisible can be broken down into parts, Sorel argues. (MKZ III, 108)

\footnotetext{
${ }^{11}$ For more about this point and the relation between myth and ideology in Miki, see Wirtz 2020.

${ }^{12}$ Miki quotes Cassirer's Philosophy of Symbolic Forms (Volume ii, 1925): "True myth does not begin when the intuition of the universe and its parts and forces is merely formed into definite images, into the figures of demons and gods; it begins only when a genesis, a becoming, a life in time, is attributed to these figures" (Cassirer 1955, 104).
} 
Miki's reading of Sorel is rather orthodox. Myth is something intuitive that avoids discursive and analytical rationalization. Its force lies here. Anyway, here also is where Miki finds the politically dangerous uses of myth. When myth's irrationality becomes an end in itself, then the myth becomes a pathological and instrumental dogma. According to Miki, Sorel's mistake is to identify the bourgeoisie with reason:

The proletariat should eliminate not only bourgeois ideology but also all theory and theory itself, since all theoretical things belong to the bourgeoisie. In this way, too, the syndicalists dismiss political means, which they regard as purposive, as a means of securing the peace, and appeal to the general strike, which they believe to be spontaneous. (MKZ III, 115-116)

The rejection of theory is not just a philosophical but a political mistake. Even if Miki accepts Sorel's distinction between utopia and myth, in which utopia is an intellectual construct moved by a certain agenda seeking to shift attention from the present to an abstract future, this does not mean that myth itself has to be purely unmediated.

In his late writings, where Miki gradually moves away from Marxist terminology, myth is incorporated as a moment of change, but also as something that should be, at some point, mediated by institutionalization and logos. This point is not far from Kōsaka's, according to which myth is only the periphery of history and therefore has to be transformed through reason. "Mythology thus contains the moment for selfnegation in the state and the nation, and objectifies itself as scholarship, art, law, etc., but everywhere it must preserve its significance as the source of its own history and as the forerunner of history" (Kōsaka 1942, 51). ${ }^{13}$ Mythology is self-negated and, through negation, a nation moves from the periphery to the center of history:

But is not the historical periphery an incomplete historical expression of such an attachment to life? The series from rumor to myth, from fashion to custom, has an expressive meaning for the group that lives within it, as long as that group lives, and as long as it is recognized, but perhaps it does not have an independent meaning of its own. It is an expression within life, but hardly an expression beyond life. What, then, is the central expression? (Kōsaka 2002, 82)

For both authors, myth should be superseded at a certain point to enable social progress. ${ }^{14}$ If there is tension between these two philosophers, it is perhaps not found

\footnotetext{
${ }^{13}$ For this reason, a mere "natural people" (Naturvolk) cannot become historically relevant. As Kōsaka says in Chīo Kōron: "The folk [民族] in itself is meaningless. When a folk gains subjectivity [主体性] they necessarily turn into a national folk [国家的民族]. Folks without subjectivity or self-determination [自己限定], that is, folks that have not transformed themselves into nations [国民], are powerless. For instance, a folk like the Ainu could not gain independence, and has eventually been absorbed into other folks [that has been transformed into] a nation" (quoted in Sakai 1997, 167).

${ }^{14}$ For this reason, for Kōsaka a nation (民族) has to become a nation-state (国家民族). As Sakai puts it: "The natural community (Kōsaka refers to it as 'substratum') is not a subject in itself, for it has yet to be
} 
here but instead in that which Kōsaka terms the verticality of myth. If so, it might be useful to look into a discussion between Kōsaka and Miki that took place in 1941. In December of that year, the literary magazine Bungei published a discussion between Kōsaka and Miki about Kōsaka's national philosophy. Myth is not a subject of the debate. Thus, one must read between the lines to appreciate how their understanding of myth is reflected in their conception of the nation and its status as an historical subject.

The counterpoint begins when Miki asks if it is possible to think that something comparable to innate "natural" talent exists in peoples. For Kōsaka, such a predetermination would undermine the historical character of the nation. In response, Miki, apparently playing the role of "devil's advocate" (see Rhydwen 2016, 198), insists that without natural qualities, the nation would be the same as a social class (see Kōsaka and Miki 1941, 7). Kōsaka appeals here once again to the notion of historical nature. "As for the possibility of history, there is a point where nature can become a material to create history" (Kōsaka and Miki 1941, 7). This material assumes the form of subjectivity. Apart from factors such as soil, blood relations, religion, and language, what ultimately constitutes a nation is, according to Kōsaka, its self-determination, its capacity to be a subject. What annoys Miki about this stance is the rejection of world subjectivity through the hypostatization of nations. Why should nations and not the world itself be the subject of world history? As Miki points out, "For example, in today's Japan, the continental expansion is explained as an impulse of self-preservation of the Japanese nation" (Kōsaka and Miki 1941, 9). In doing so and making the nation and not the world the place of historical subjectivity, Kōsaka is dangerously risking crossing the border into a type of biologicist legitimization of colonization. Although he rejects the imperialist idea of mediation, according to which some nations are "mediated" by other more powerful ones, and then disappear, conflict cannot be avoided in the global dynamic described by him. Only nation-states are able to fill the position of historical agents because only nation-states are able to determine themselves:

I think it is necessary to make use of these things [sc. the concept of the eternal now] in the reality of history, not just as words that may or may not exist. Then, it must be something that can demand absoluteness in the flow of time. If we were to seek such absolutes in reality, wouldn't the kind of authority that the state possesses be it? Of course, there is moral authority for the individual. But that authority is only what it ought to be. But when it comes to state authority, the situation is different. Even if someone tries to negate it, the authority of the state cannot be negated on its own. On the contrary, it negates those who negate it. (Kōsaka and Miki 1941, 12)

This last point explains why, for Kōsaka, authority is so important. The verticality of authority is what determines that a nation can move toward historical centrality, adopting the position of a nation-state. Thus, he says that the authority of a group "has a metaphysical background" (Kōsaka 1942, 61). This ground is none other than the "eternal now". "Moreover, the group's authority is established, for this reason, a priori

rationalized. The natural community must be represented by the state; only through the state, the natural community is identified as the nation for itself" (Sakai 1997, 166). 
at the historical origin of its possibility" (Kōsaka 1942, 45). In this sense, Kōsaka explicitly affirms that the authority of the state rests in the "realization of the eternal now" (Kōsaka 1942, 64). History is understood because nations carry the historical events in themselves, on the basis of their natural substrate. "The society, the nation, is the storehouse of historical time" (Kōsaka 1942, 64).

The gap between Kōsaka and Miki becomes clearer now. For both thinkers, myth has a double root. One is nature, the other is history. For Miki, the natural side of myth is what he terms the "pathetic", that is, the embodied and situational affectivity of the present toward the past. By contrast, for Kōsaka, this naturalness is based on the facticity of the eternal now. Kōsaka's distinction between primordial, environmental, and historical nature does not solve the tension between nature and history. Miki's suspicion shows that, even if he is reluctant to admit it, he might have introduced an undercover naturalism to his analysis. At best, Kōsaka must admit that nature and history are co-original, but he must abandon the attempt to provide an explanation for it.

\section{THE RESISTANCE OF MYTH}

To conclude, I would like to summarize Kōsaka's reflections on myth, point out their problems, and suggest an alternative (more benevolent) reading. The myth is for Kōsaka a central element of societies. There seems to be a mythical moment that is especially important for Kōsaka - the moment in which authority manifests itself through myth. Paradoxically, the highest point of this mythical mechanism is also the overcoming of myth. "A nation is essentially a state, that is, self-limiting and authoritative [権威的]. And this can be seen in the mythical consciousness of the nation" (Kōsaka 1942, 33). In order to recognize itself as such, a nation needs the verticality of myth, that is, to refer its own present to a remote past. This union between present and past is not, however, natural, but something intermediate between the natural and the contractual. To be able to distance oneself from nature is in itself an act of historical freedom, a performative act that creates mythical authority. Myth, in its aspect closest to nature and custom, must be overcome by a moment of radical verticality. Myth is always vertical, but there is a political verticality that transcends natural verticality. This is no other than the difference between a totem and a national identity. Furthermore, this ambiguity is not surprising, since we saw how Kōsaka has difficulty separating nature from history. Myth stays at the crossroads, between both. As mentioned earlier, a nation that remains in its natural periphery cannot be truly selfdetermining. A nation then becomes such when it becomes the vehicle of authority. But if the moment of nationalization depends on the vertical interference of the eternal now, the objection would be that this implies an apriorization qua naturalization of the historical process. "The historical center is submerged within the divine, both expressively and practically. The historical center can well be the historical center only because it is supra-historical [超歴史的]” (Kōsaka 2002, 89). Here, Kōsaka's words do not help with escaping this dead end. By rendering nature historical, Kōsaka is almost naturalizing history. The only element that allows us to find a way out of this 
problem is the past. The particularity of myth seems to be its link with the past, its pastness. In this, it differs from nature. Although nature possesses a past, it does not possess it in the same way that it appears in myth as something "already" there. The authority of myth, then, is not merely natural but is granted by the past. It matters little whether this past is real or virtual. Its pastness gives it its authoritative dimension. In this sense, the absolute present can present itself as such without normative and pretemporal becoming.

As Miki observes, this point is philosophically and politically problematic. Myth for Miki is a moment of imagination and change, guided by the affectivity of the present and not by the weight of the past. In that sense, Miki seems reluctant to reify the nation. ${ }^{15}$ Kōsaka uses myth to indicate the ground of nationality itself. This past-oriented interpretation of myth cannot avoid the problem of metaphysical or ideological predeterminism.

Nevertheless, using his profound reflections on the vertical-temporal character of myth, moving beyond Kōsaka becomes possible. Verticality implies a certain kind of predestination if we think of it as something supra-mundane. But myth can be something that resists any form of actualization, even as something transcendental. In this sense, myth appears as "already there" because it cannot be fully actualized at any point in history. While this is reminiscent of utopia, there is a fundamental difference. Indeed, the purpose of utopia is to generate the false idea of change (a sort of gatopardism). In contrast, the purpose of myth is to generate temporal dislocations. The resistance of the myth does not limit its potentiality. This "resistance" does not mean that myth is static; on the contrary, it is the condition for its transformation as something that withdraws itself constantly. Perhaps this has something to do with the self-negating principle included in myth that makes it move toward that which transcends myth. For this reason, myth is neither "outside" nor "inside" but rather "before" history (see Kōsaka 1942, 46). But if myth is always to remain virtual, its "authority" becomes double-edged - foundational and at the same time ungraspable and disruptive. In this sense, Kōsaka's important contribution is that he vindicates the role of the historical periphery as a dimension of historical relevance. A further development of Kōsaka's thought could thus contribute to thinking of the autonomy of myth as a historical and at the same time ancestral sphere that allows articulating the political with the anthropological and religious.

\footnotetext{
${ }^{15}$ In this sense, he says to Kōsaka: "The present day theory of nation is finally a Machiavellianism. It is something made in order to create political myths [政治的な神話]" (Kōsaka and Miki 1941, 16). As Tsuda puts it: "In contrast to Kōsaka's argument that 'the nation is the embodiment of the ethnic group' and the 'absolute authority' of the 'national ethnic group', Miki rather separates the nation from the ethnic group and tries to relativize the absolute authority of the "national ethnic group"' (Tsuda 2006, 36).
} 


\section{ACKNOWLEDGEMENTS}

I thank the anonymous reviewers of the journal Comparative Philosophy whose suggestions helped improve and clarify this manuscript. This work was supported by the Fritz Thyssen Foundation.

\section{REFERENCES}

Antoni, Klaus (2002), "Shintō and Kokutai: Religious Ideology in the Japanese Context," in K. Antoni et al. (eds.) Religion and National Identity in the Japanese Context, (Münster/Hamburg/London: Transaction), 263-287.

Antoni, Klaus (2011), "Creating a Sacred Narrative - Kojiki Studies and Shintō Nationalism 1," Japanese Religions 36.1\&2: 3-30.

Cassirer, Ernst (1955), The Philosophy of Symbolic Forms. Volume II: Mythical Thought (New Haven: Yale University Press).

Freyer, Hans (1926), Der Statt [The State] (Leipzig: Ernst Wiegandt).

Goto-Jones, Christopher S. (2008), Re-politicising the Kyoto School as Philosophy (London/New York: Routledge).

Hanazawa, Tetsufumi 花澤哲文 (2008), 『高坂正顕。京都学派と歴史哲学』 [Masaaki Kōsaka. The Kyoto School and the Philosophy of History] (Kyoto: Toeisha).

Harootunian, Harry (2019), Uneven Moments: Reflections on Japan's Modern History (New York: Columbia University Press).

Hase, Shōtō 長谷川正當 (2002), 「解説」[Commentary], in M. Kōsaka (auth.); S. Hase (ed.) 『歴史的世界』(Kyoto: Toeisha), 308-343.

Hertz, Frederick (1915), Rasse und Kultur; eine kritische Untersuchung der Rassentheorien [Race and Culture; a Critical Examination of Theories of Race] (Leipzig: A. Kröner).

Isomae, Jun'ichi 磯前順一 (2010), Japanese Mythology. Hermeneutics on Scripture (Kyoto/London: Equinox).

Kōsaka, Masaaki 高坂正顕 (1941), 『神話。解釈学的考察』[Mythology. Hermeneutic Considerations] (Tokyo: Iwanami).

Kōsaka, Masaaki 高坂正顕 (1942), 『民族の哲学』[Philosophy of the Nation] (Tokyo: Iwanami).

Kōsaka, Masaaki 高坂正顕 (2002), 『歴史的世界』[The Historical World] (Kyoto: Toeisha).

Mauss, Marcel (1966), The Gift. Forms and Functions of Exchange in Archaic Societies (London: Cohen \& West).

MKZ: Miki, Kiyoshi 三木清 (1966-1968)，『三木清全集』[Complete Works of Miki Kiyoshi] (Tokyo: Iwanami Shoten). 
Miki, Kiyoshi and Kōsaka, Masaaki (1941), 「民族の哲学。対談」[Philosophy of the Nation. A Conversation], Bungei 9.12: 2-21.

Moret, Alexandre and Davy, Georges (1926), From Tribe to Empire. Social Organization among Primitives and in the Ancient East (New York: Alfred Knopf).

Nicholls, Angus (2006) Goethe's Concept of the Daemonic: After the Ancients (New York: Camden House).

NKZ: Nishida, Kitarō 西田幾多郎 (1947-1953), 『西田幾多郎全集』[Complete Works of Nishida Kitarō] (Tokyo: Iwanami Shoten).

Nishida, Kitaro 西田幾多郎 (2012), Ontology of Production: Three Essays (Durham, NC: Duke University Press).

Ratzel, Friedrich (1909), Anthropogeographie. Erster Theil: Gründzuge der Anwendung der Erdkunde auf die Geschichte [Anthropogeography. First Part: Foundations of the Application of Geography to History] (Stuttgart: J. Engelhorn). Rhydwen, Thomas Parry (2016), "The Kyoto School and Confucianism: a Confucian Reading of the Philosophy of History and Political Thought of Masaaki Kōsaka" (Cork: University College Cork). [Dissertation]

Sakai, Naoki 酒井直樹 (1997), Translation and Subjectivity: On “Japan” and Cultural Nationalism (Minneapolis: University of Minnesota Press).

Sugawara, Jun 菅原潤 (2018), 『京都学派』[The Kyoto School] (Tokyo: Kodansha).

Tönnies, Ferdinand (1909), Die Sitte [Custom] (Frankfurt am Main: Rütten und Loening).

Tönnies, Ferdinand (1922), Gemeinschaft und Gesellschaft: Grundbegriffe der reinen Soziologie [Community and Society: Basic Concepts of Pure Sociology] (Berlin: K. Curtius).

Tsuda, Masao 津田雅夫 (2006), 「【自然】と【人為】：三木清覚書(2)」[Nature and Humanity: Notes on Miki Kiyoshi (2)], Research Report, Faculty of Regional Science, Gifu University 18: 41-42.

Uhl, Christian (2007), "What was the 'Japanese Philosophy of History'? An Inquiry into the Dynamics of the 'World-Historical Standpoint' of the Kyoto School," in C.S. Goto-Jones (ed.) Re-politicising the Kyoto School as Philosophy (New York: Routledge), 113-133.

Weber, Max (1922), Wirtschaft und Gesellschaft [Economy and Society] (Tübingen: Mohr Siebeck).

Wirtz, Fernando (2020), "Myth and Ideology in Miki Kiyoshi," European Journal of Japanese Philosophy 5: 75-102.

Yōko, Isse 一瀬陽子 (2019), “Revisiting Tsuda Sōkichi in Postwar Japan,” Japan Review 34:139-160. < doi/10.15055/00007411>

Zavala, Agustín Jacinto (2004), Tradición y mundo histórico en la filosofía de Nishida Kitarō [Tradition and Historical World in the Philosophy of Nishida Kitarō] (Michoacán: El Colegio de Michoacán). 